SAND76-8063

Unlimited Release

\title{
Fabrication, Classification, and Characterization of Tellurium Powders
}

\author{
R. M. German, V. Ham
}

Prepared by Sandia Laboratories, Albuquerque New Mexico 87115

and Livermore, California 94550 for the United States Energy Research

and Development Administration under Contract AT (29.1) 789

Printed January 1977

When printing a copy of any digitized SAND Report, you are required to update the markings to current standards. 
Issued by Sandia Laboratories, operated for the United States Energy Research and Development Administration by Sandia Corporation.

\section{NOTICE}

This report was prepared as an account of work sponsored by the United States Government. Neither the United States nor the United States Energy Research and Development Administration, nor any of their employees, nor any of their contractors, subcontractors, or their employees, makes any warranty, express or implied, or assumes any legal liability or responsibility for the accuracy, completeness or usefulness of any information, apparatus, product or process disclosed, or represents that its use would not infringe privately owned rights. 
SAND76-8063

Unlimited Release

Printed January 1977

\title{
FABRICATION, CLASSIFICATION, AND CHARACTERIZATION \\ OF TELLURIUM POWDERS
}

\author{
R. M. German \\ V. Ham \\ Metallurgy and Electroplating Division 8312 \\ Sandia Laboratories, Livermore
}

\begin{abstract}
Tellurium powder is used as a constituent in heat-producing, thermite-type reactions. In such reactions, long-term stability and reaction rate considerations require a compromise between surface area and particle size. To meet these requirements, a spherical powder was fabricated by atomizing liquid tellurium. In general, air classification techniques proved to be the most successful means of removing adherent fines from tellurium powders. Development of a minimum set of standard powder characterization techniques is outlined and applied to several spherical and irregular tellurium powders.
\end{abstract}




\section{ACKNOWLEDGMIENTS}

The author wishes to acknowledge C. W. Karfs for his microscopy efforts. 


\section{TABLE OF CONTENTS}

$\begin{array}{lc}\text { Introduction } & \text { Page } \\ \text { Tellurium Powder Technology } & 13 \\ \quad \text { Powder Characterization } & 13 \\ \quad \text { Powder Fabrication } & 14 \\ \quad \text { Powder Classification } & 15 \\ \text { Development of an Optimal Tellurium Powder } & 18 \\ \text { Summary } & 18 \\ \text { Appendix A--Powder Characterization Techniques Outline } & 25 \\ \text { Appendix B--Tellurium Atomization } & 31 \\ \text { References } & 33 / 34\end{array}$




\section{ILLUSTRATIONS}

$\underline{\text { Figure }}$

$\underline{\text { Page }}$

1. Scanning Electron Micrographs of Commercial Te Powders

2. Atomized Te Powder Before Air Classification

3. Te Powder Classified Into a $-44+37 \mu \mathrm{m}$ Size Fraction by Screening; Fines Not Removed

4. Te Powder Classified by Repeated Water Washings; Fines Not Removed

5. Te Powder Classified by Repeated Air Elutriation; Fines Removed

6. Te Powder Classified by Ultrasonic Agitation of a Liquid Slurry Followed by Wet Sedimentation; Majority of Fines Removed

7. $+300 \mu \mathrm{m}$ Spherical Te Powder

8. 100 to $300 \mu \mathrm{m}$ Spherical Te Powder

9. 53 to $100 \mu \mathrm{m}$ Spherical Te Powder

10. 37 to $53 \mu \mathrm{m}$ Spherical Te Powder

11. 20 to $37 \mu \mathrm{m}$ Air Classified Spherical Te Powder

12. $-20 \mu \mathrm{m}$ Air Classified Spherical Te Powder

13. Ziess Particle Size Distributions for the Three Spherical Te Powders Shown in Figures 9, 10, and 11, and the AirElutriated Irregular Te Powder Shown in Figure 5. 
Page

14. Optical Micrograph of Polished Cross Sections Through the 53 to $100 \mu \mathrm{m}$ Te Spheres

15. Polarized Light Micrograph Showing the Grain Structure in the 53 to $100 \mu \mathrm{m}$ Spherical Te Powder

16. 53 to $100 \mu \mathrm{m}$ Spherical Te Coated With Tungsten 
TABLES

Table

I. Approaches to Tellurium Particle Size Analysis 16

II. Tellurium Powder Classification Approaches 19

III. Classified Atomized Tellurium $\quad 27$ 


\title{
FABRICATION, CLASSIFICATION, AND CHARACTERIZATION OF TELLURIUM POWDERS
}

\author{
Introduction
}

\begin{abstract}
Sandia Laboratories' interest in tellurium (Te) powder is as a constituent in explosive and thermite devices. In these devices, the reaction enthalpy during rapid alloying with a metal (like Co) produces an intense heat. However, two of the design criteria for such devices imply contrasting powder properties. To ensure rapid and complete alloying, a fine Te particle size is needed. On the other hand, the design requirement for longterm stability implies a small surface area (i. e., large particle size) to minimize interfacial reactions. The need for a balance between these contrasting Te powder characteristics led to a development effort devoted to assessing various approaches for Te powder fabrication, classification, and characterization. Although this presentation is not comprehensive, it does establish an initial basis for formulating material specifications for future studies.
\end{abstract}

\section{Tellurium Powder Technology}

Physical powder characteristics such as size and packing density have strong influences on thermite reaction rates, heat intensity, and overall system stability. Thus, to develop the relations between thermite reaction properties and powder characteristics is a desirable goal. Such a goal requires powder samples with known property variations, which, in turn, requires a suitable means of characterizing each powder sample. For this reason, considerable emphasis was placed on developing powder characterization techniques applicable to Te. Furthermore, quantitative evaluation of the various fabrication and classification approaches explored in this program relied on development of quantitative characterization techniques. The intent was not to create a comprehensive powder characterization schedule, but rather to establish the minimum set of measurements necessary to characterize each powder. 


\section{Powder Characterization}

The important powder properties are the size distribution, particle shape, interparticle friction, and internal particle structure. 1 Obviously, the particle size is influential because chemical reactivity is inversely dependent on the particle diameter (i. e., directly dependent on the specific surface area). For example, the Kelvin equation for vapor pressure and the Freundlich-Ostwald equation for solubility both exhibit the same particle size dependence: ${ }^{2}$

$$
\ln \left(P / P_{o}\right)=\ln \left(C / C_{o}\right)=2 \gamma V / k T d
$$

where $P_{O}=$ vapor pressure, $P=$ vapor pressure over a curved surface, $\mathrm{C}=$ solubility, $\mathrm{C}_{\mathrm{O}}=$ solubility of the material without curvature, $\gamma=$ surface energy, $\mathrm{V}=$ molar volume, $\mathrm{k}=$ Boltzmann's constant, $\mathrm{T}=$ temperature, and $\mathrm{d}=$ particle diameter (assumed spherical). Equation (1) illustrates the increased chemical activity which results from a reduced particle size. In a powder sample with a wide size distribution, the fines segment have the greatest influence on chemical reactivity. With respect to a thermite reaction, the specific surface area $S$ is an ideal measure of the reactivity. The specific surface area relates to the mean particle diameter on a population basis $\left(\bar{d}_{N}\right)$ as

$$
S=\frac{6}{\rho \bar{d}_{N}}
$$

where $\rho=$ theoretical density $\left(6.24 \mathrm{~g} / \mathrm{cm}^{3}\right.$ for $\left.\mathrm{Te}\right)$. One aspect of the surface area important to the present study is that it is influenced mostly by the finer particles. If a weight distribution is known, the mean particle size $\bar{d}_{W}$ can be used to approximate $\bar{d}_{N}$ (and thereby calculate $S$ from Equation (2)) as follows: ${ }^{3}, 4$

$$
\ln \overline{\mathrm{d}}_{\mathrm{W}}=\ln \overline{\mathrm{d}}_{\mathrm{N}}+3 \ln ^{2}{ }_{\mathrm{g}}
$$

where $\sigma_{\mathrm{g}}$ is the geometric standard deviation of the distribution. Thus a relative measure of chemical reactivity can be established by determining either the specific surface area or the particle size distribution. For this study, the specific surface area was measured routinely by nitrogen adsorption and supplemented with size distribution information whenever appropriate.

Besides the particle size, the particle shape is important in that a locally small radius of curvature (e.g., a sharp corner) can act to increase the chemical reactivity. That is, d in Equation (1) can actually be thought of as a radius of curvature. Also, the particle shape and size distribution control the powder-packing properties through the interparticle friction. 
For thermite reactions, where large heat densities are sought, uniformly sized, dense, spherical particles will give better powder packing. Typically these friction properties can be qualitatively compared by microscopy or quantitatively assessed by the apparent and tap densities of the powder. 5 Finally, the fourth important parameter is the internal structure. Generally, this structure is most appropriately analyzed by standard optical metallography techniques as applied to random cross sections through mounted and polished particles. Metallographic analysis will provide information on the internal porosity, grain structure, and degree of particle agglomeration.

It was found that scanning electron microscopy combined with nitrogen adsorption specific surface area proved adequate for an initial powder characterization. If interest in a powder warranted further effort, these techniques were supplemented with optical metallography and particle size analysis. A variety of techniques for particle size analysis 6,7 were surveyed for their applicability to the Te powders. Table I summarizes these techniques and gives comments on their applicability. As shown, the relative toxicity of Te prevented some approaches properly suited to these powders from being pursued. Of these techniques, both the Zeiss and Coulter instruments proved adequate for determining the particle size distribution and were used on several powder lots during this study. Further details of the characterization techniques are given in Appendix A.

\section{Powder Fabrication}

Tellurium's brittle nature makes powder fabrication by attrition or pulverization quite easy. Such mechanical powder fabrication processes resulted in undesirable angular particles. In addition, these processes also generate a considerable amount of adherent fines during the commuting of wrought Te. Figure 1a shows a scanning electron micrograph of a typical powder sample produced by attrition. Removal of the adherent fines proved to be a major problem with this powder, as will be discussed in the next section. The alternative powder production method commercially applied to Te is electrochemical precipitation. A typical precipitated powder is shown in Figure 1b. No consideration was given to this powder because of high impurity levels, amorphous nature, high reactivity, fine size, and poor packing characteristics.

The powder fabrication technique eventually developed in this program was based on inert gas atomization of liquid Te. The spherical shape of powders produced by this process is an attractive characteristic. Furthermore, spherical particles provide high packing densities and are easily classified into narrow size ranges by means of conventional equipment. The typical powder appearance following atomization is shown in Figure 2. It was found that the powder size distribution could be controlled by the atomization parameters. Details of the atomization approach are given in Appendix B. 
TABLE I

APPROACHES TO TELLURIUM PARTICLE SIZE ANALYSIS

\begin{tabular}{|c|c|c|c|}
\hline Technique & Principle & Problems & Comments \\
\hline Coulter & $\begin{array}{l}\text { Electrolyte resistivity changes } \\
\text { in a small volume dependent } \\
\text { on particle size }\end{array}$ & $\begin{array}{l}\text { Large particles selectively } \\
\text { settle from the electrolyte }\end{array}$ & $\begin{array}{l}\text { Proved valuable } \\
\text { on powders under } \\
\sim 40 \mu \mathrm{m}\end{array}$ \\
\hline Zeiss & $\begin{array}{l}\text { Optical comparison to photo- } \\
\text { micrographs }\end{array}$ & $\begin{array}{l}\text { Must photographically } \\
\text { resolve particles without } \\
\text { agglomeration }\end{array}$ & $\begin{array}{l}\text { Proved valuable on } \\
\text { coarser powders }\end{array}$ \\
\hline Micromerograph & $\begin{array}{l}\text { Stoke's law sedimentation } \\
\text { in air }\end{array}$ & $\begin{array}{l}\text { Air exposure of Te posed } \\
\text { toxicity problem }\end{array}$ & Not used \\
\hline Sedigraph & $\begin{array}{l}\text { Stoke's law sedimentation } \\
\text { in liquid }\end{array}$ & $\begin{array}{l}\text { Limited to size range } 0.2 \\
\text { to } 50 \mu \mathrm{m} \text {, must know some } \\
\text { powder characteristics }\end{array}$ & $\begin{array}{l}\text { Did not break apart } \\
\text { agglomerates }\end{array}$ \\
\hline Sedibal & Same & $\begin{array}{l}\text { Requires extensive calcu- } \\
\text { lations to perform an } \\
\text { analysis }\end{array}$ & Not used \\
\hline Centrifuge & Same & Same & Same \\
\hline $\begin{array}{l}\text { Precision } \\
\text { screening }\end{array}$ & $\begin{array}{l}\text { Collect particles on stacked } \\
\text { screens with known openings }\end{array}$ & $\begin{array}{l}\text { Screens become blocked } \\
\text { with fines; must be used in } \\
\text { glove box }\end{array}$ & $\begin{array}{l}\text { Did not separate } \\
\text { fines from coarse }\end{array}$ \\
\hline
\end{tabular}



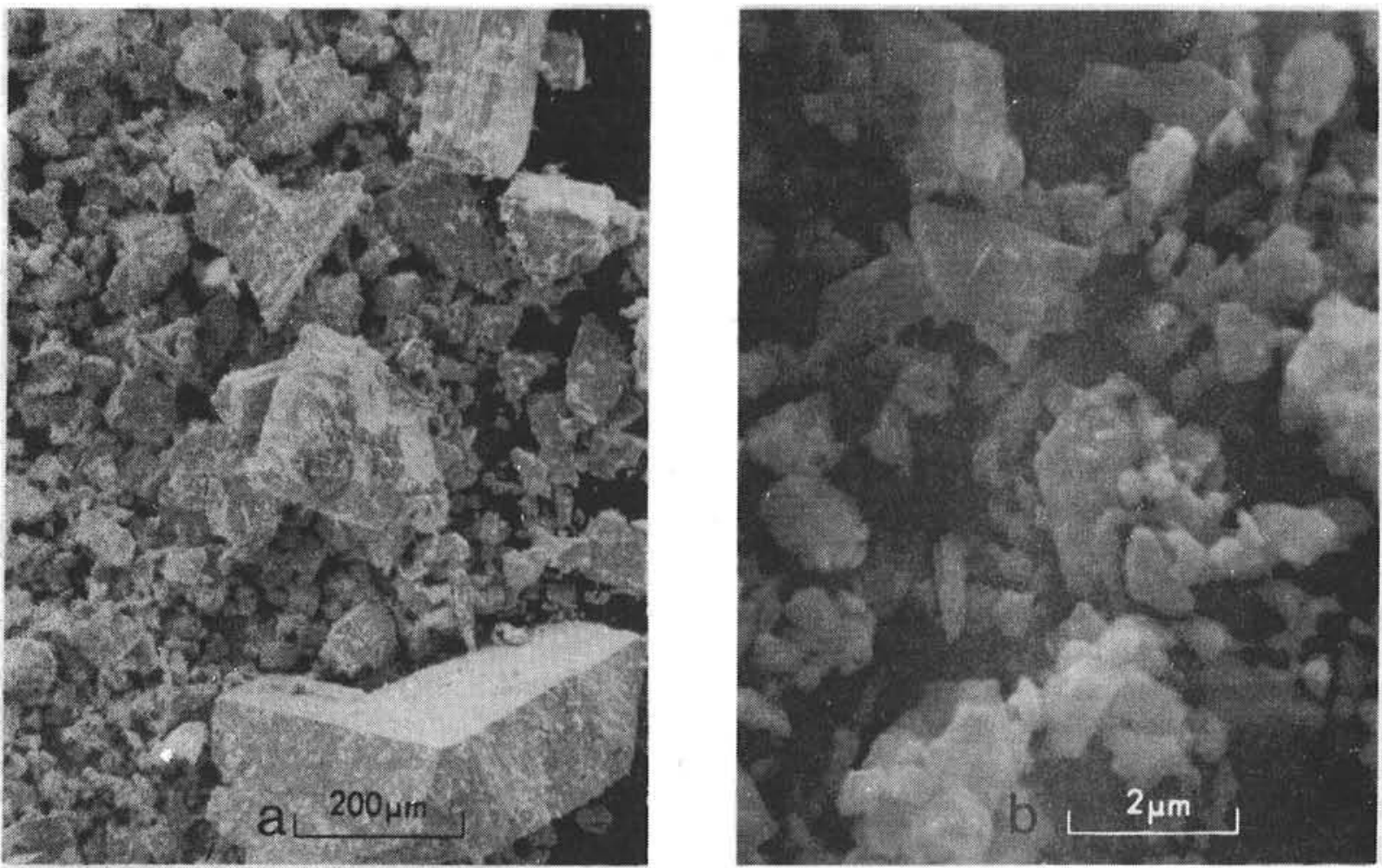

Figure 1. Scanning Electron Micrographs of Commercial Te Powders

(a) Attritioned and screened Te powder illustrating the angular particle shape and adherent fines (100 X)

(b) Electrochemical precipitated Te powder showing the very fine particle size $(10,000 \mathrm{X})$

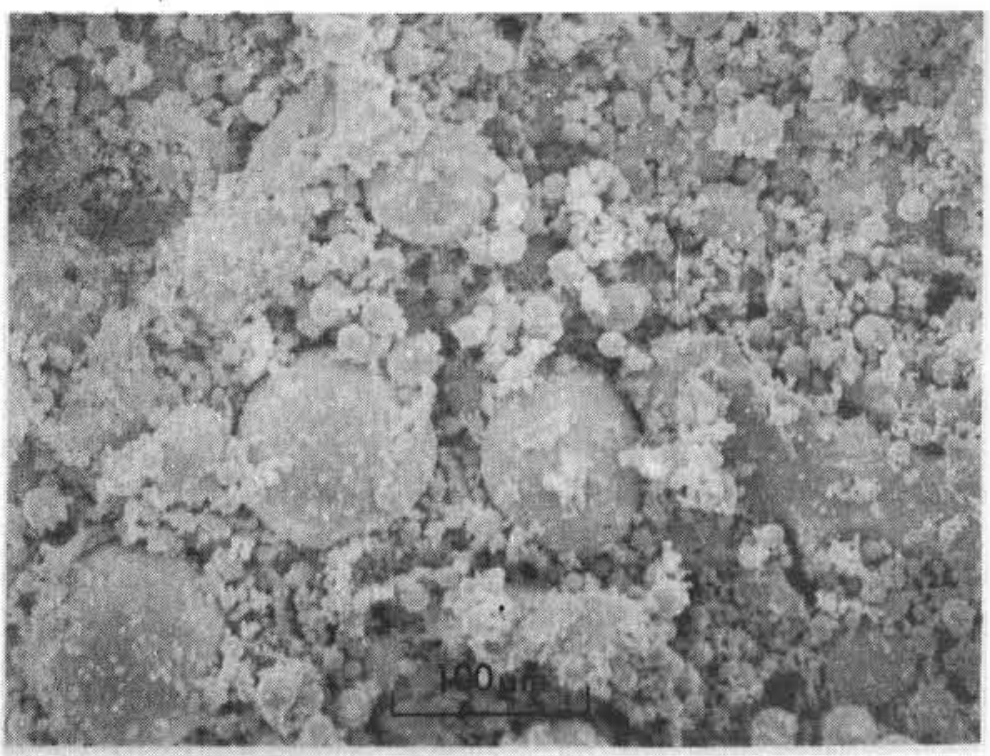

Figure 2. Atomized Te Powder Before Air Classification (200 X)

(Material source - Kawecki Berylco, Purity - 99.99\% Te, $\mathrm{S}-0.15 \mathrm{~m}^{2} / \mathrm{g}$, and $\overline{\mathrm{d}}_{\mathrm{N}}-6.3 \mu \mathrm{m}$ ) 
Powder Classification

The four techniques listed in Table II were applied to the classification of the Te powders. As a comparison aid, the specific surface areas and $\overline{\mathrm{d}}_{\mathrm{N}}$ values are listed by technique in Table II. Development of the appropriate separation approach was performed on a powder similar to that shown in Figure 1a. Examination of the micrographs in Figures 3 through 6 and consideration of the surface areas show that either ultrasonic agitation combined with wet sedimentation or air elutriation resulted in deagglomeration and significant fines removal. Air elutriation (classification) techniques are. well-developed for powder materials and do not introduce the potential contamination of the wet sedimentation technique. Hence air classification is the preferred approach. An important point is that screening is not an appropriate classification technique for irregular shaped Te powder.

Development of an Optimal Tellurium Powder

The justification for the powder characterization, fabrication, and classification development work was the eventual separation of an optimal Te powder for thermite reactions. Elimination of the fines portion of the size distribution was intended to reduce instabilities in the long-term storage of thermite mixtures. As illustrated earlier, the specific surface area is a primary factor in establishing the chemical stability of a powder mixture. With respect to shape, a spherical particle is optimal. Not only does a sphere minimize the surface area-to-volume ratio, it is also the optimal shape for air classification. In addition, a sphere is most easily coated by chemical vapor deposition; thus, a spherical particle shape is amenable to metallic coatings if they are required to ensure long-term stability. Hence, it was decided to use the atomized Te for preparation of several "optimal" powders.

The powder atomization was achieved as outlined in Appendix B from a $99.99 \%$ pure Te stock. Subsequently, the atomized powder was separated by a combination of screening and air classification into the six size fractions listed in Table III. Scanning electron micrographs of these six size fractions are shown in Figures 7 through 12 . The $+300,100$ to 300 , and $-20 \mu \mathrm{m}$ size fractions exhibited undesirable characteristics. The fines cut $(-20 \mu \mathrm{m})$ contained numerous micron-sized particles. The coarser particles (over 100 $\mu \mathrm{m}$ ) were composed of many agglomerates and irregular shaped particles. The agglomerated fine particles account for the higher-than-expected surface area for the $+300 \mu \mathrm{m}$ size fraction. Because of these undesirable properties, there was no further characterization of these three fractions. For the remaining three fractions, particle size distributions were determined from scanning electron micrographs by means of the Zeiss particle size analyzer. 
TABLE II

TELLURIUM POWDER CLASSIFICATION APPROACHES

Starting powder - irregular particles, source - ROC/RIC screened 44 to $150 \mu \mathrm{m}$

$\mathrm{S}-0.33 \mathrm{~m}^{2} / \mathrm{g}$

$\overline{\mathrm{d}}_{\mathrm{N}}-2.9 \mu \mathrm{m}$

\begin{tabular}{|c|c|c|c|c|c|}
\hline Technique & Details & Result & $\mathrm{s}, \mathrm{m}^{2} \mathrm{~g}$ & $\overline{\mathrm{d}}_{\mathrm{N}}, \mu \mathrm{m}$ & Figure No. \\
\hline Screening & $\begin{array}{l}\text { Agitated powder over } \\
\text { screens to remove } \\
-44+37 \mu \mathrm{m}\end{array}$ & $\begin{array}{l}\text { Agglomerates, adherent } \\
\text { fines }\end{array}$ & 0.41 & 2.3 & 3 \\
\hline Water wash & $\begin{array}{l}\text { Stirred powder slurry, } \\
\text { decanted fines, and re- } \\
\text { peated three times }\end{array}$ & $\begin{array}{l}\text { Eliminated agglomerates, } \\
\text { considerable adherent } \\
\text { fines remained }\end{array}$ & 0.33 & 2.9 & 4 \\
\hline Air elutriation & $\begin{array}{l}\text { Classification by } \\
\text { creating air flow which } \\
\text { shears fines from pow- } \\
\text { der surface (repeated } \\
3 \text { times) }\end{array}$ & $\begin{array}{l}\text { Good, no agglomerates, } \\
\text { few fines }\end{array}$ & 0.15 & 6.4 & 5 \\
\hline $\begin{array}{l}\text { Ultrasonic } \\
\text { agitation plus } \\
\text { wet sedimenta- } \\
\text { tion }\end{array}$ & $\begin{array}{l}\text { Added Daxad } 23 \text { as } \\
\text { wetting agent to wet } \\
\text { powder, ultrasonic plus } \\
\text { decant fines (repeat } 3 \\
\text { times) }\end{array}$ & $\begin{array}{l}\text { Few fines, no } \\
\text { agglomeration }\end{array}$ & 0.12 & 8.0 & 6 \\
\hline
\end{tabular}




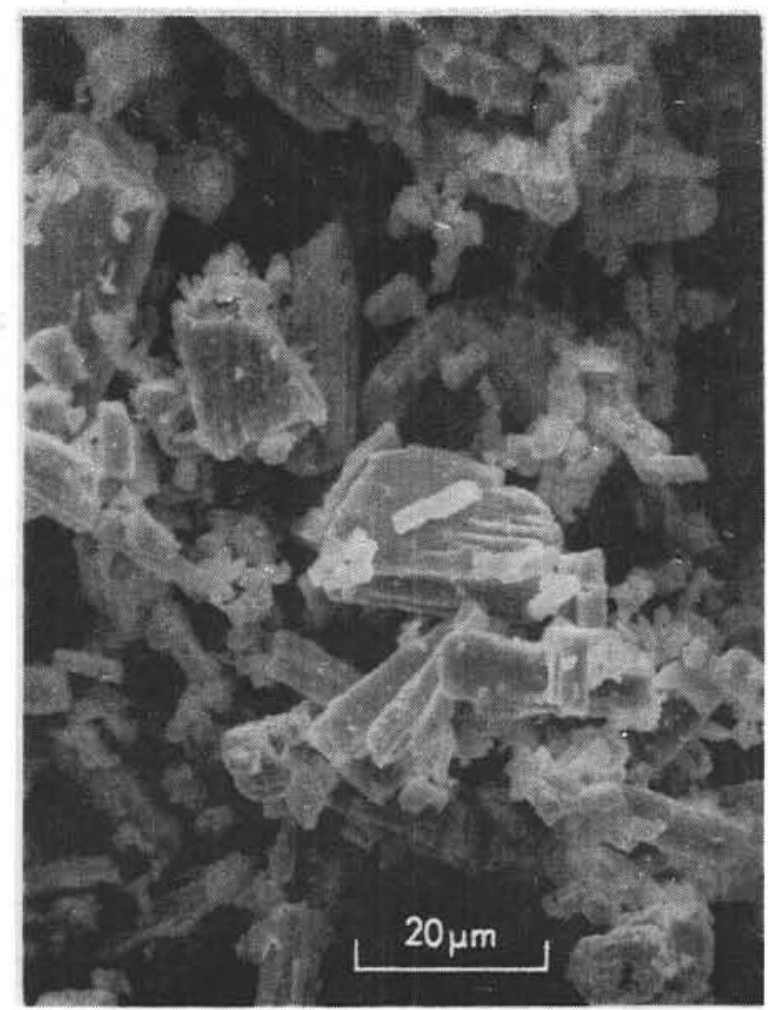

Figure 3. Te Powder Classified Into a $-44+37 \mu \mathrm{m}$ Size Fraction by Screening; Fines Not Removed ( $1000 \mathrm{X})$ (Material source - Research Inorganics (ROC/RIC), and purity - $99 \% \mathrm{Te}$ )

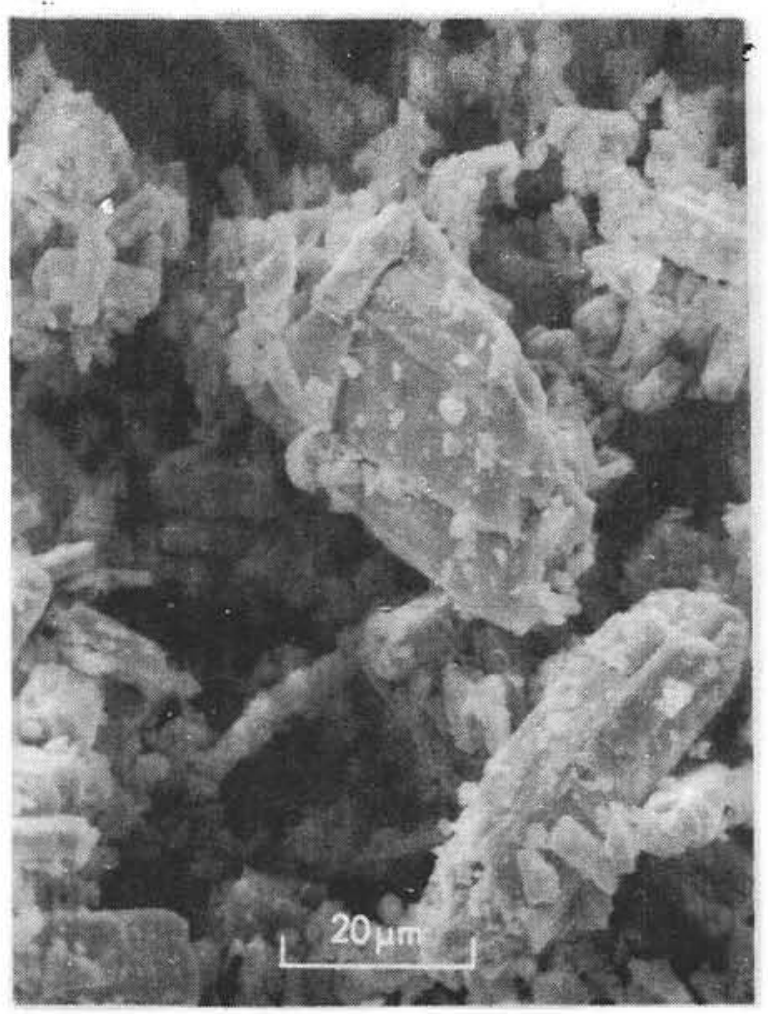

Figure 4. Te Powder Classified by Repeated Water Washings; Fines Not Removed (1000 X)

(Material source - Research Inorganics, Purity - 99\% Te, and Screened $-150+44 \mu \mathrm{m}$ ) 


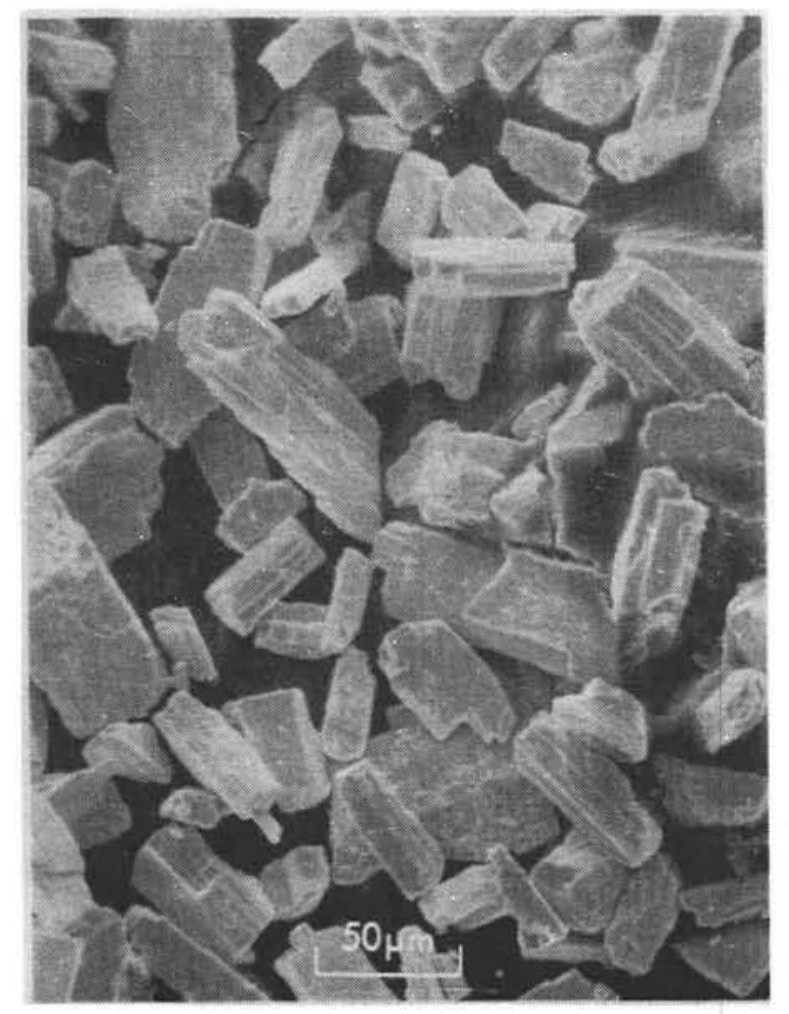

Figure 5. Te Powder Classified by Repeated Air Elutriation; Fines Removed (300 X)

(Same starting material as shown in Figure 4)

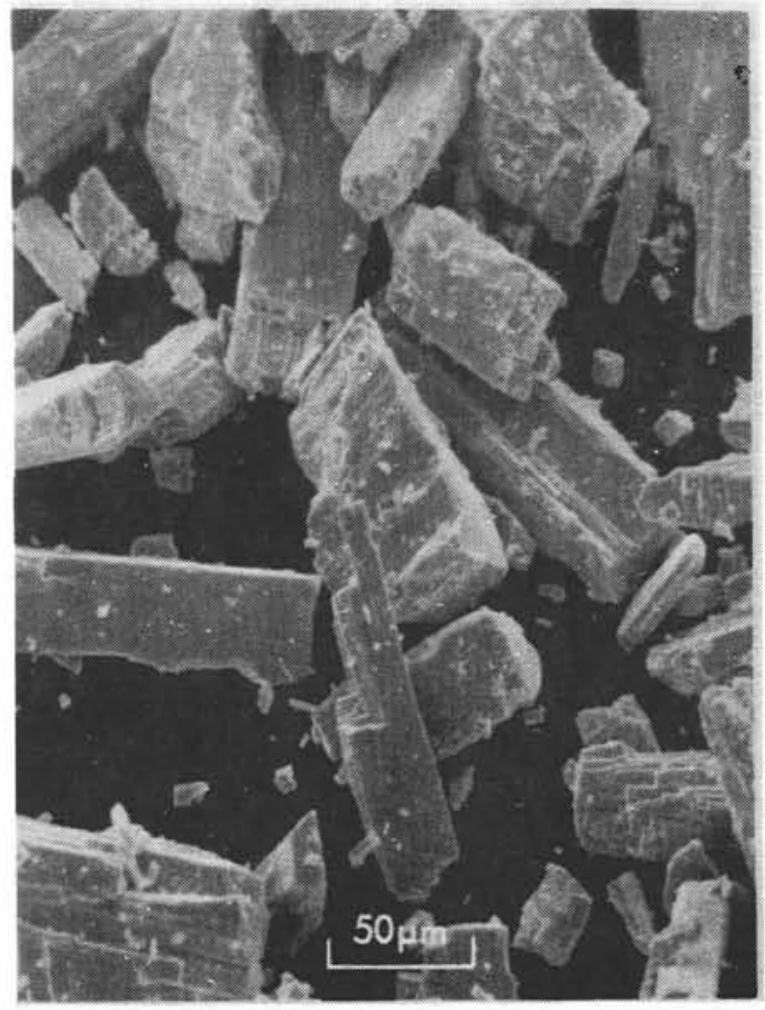

Figure 6. Te Powder Classified by Ultrasonic Agitation of a Liquid Slurry Followed by Wet Sedimentation; Majority of Fines Removed (300 X)

(Same starting material as shown in Figures 4 and 5) 


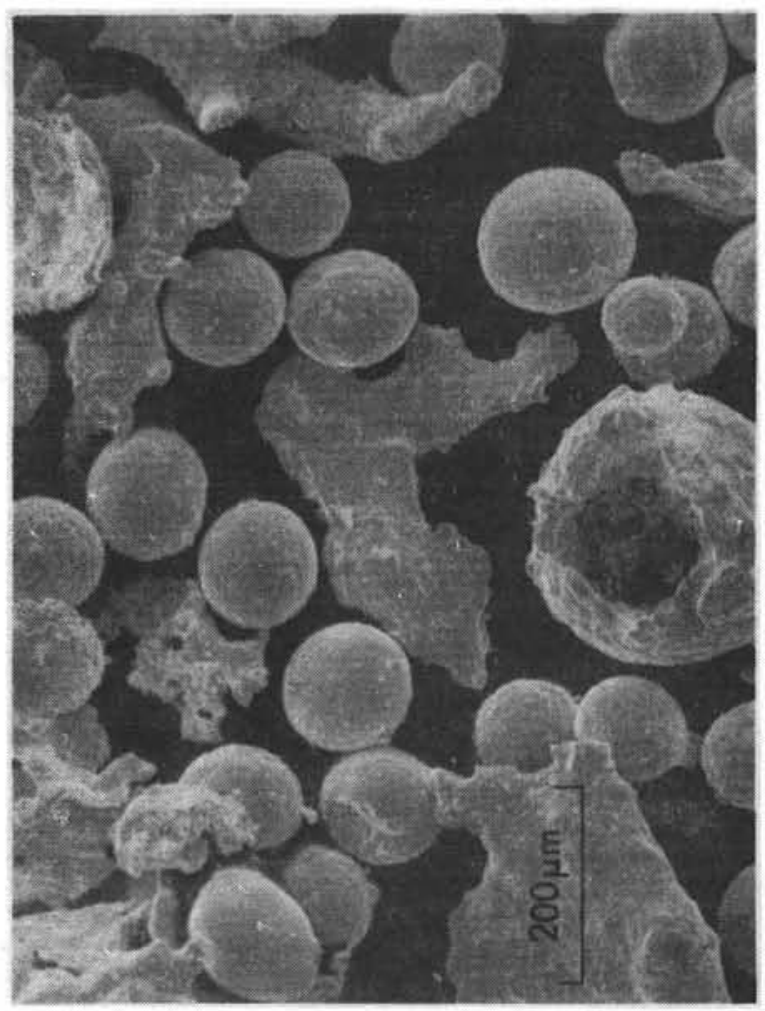

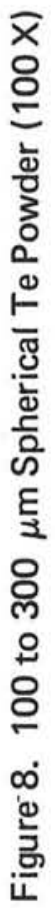

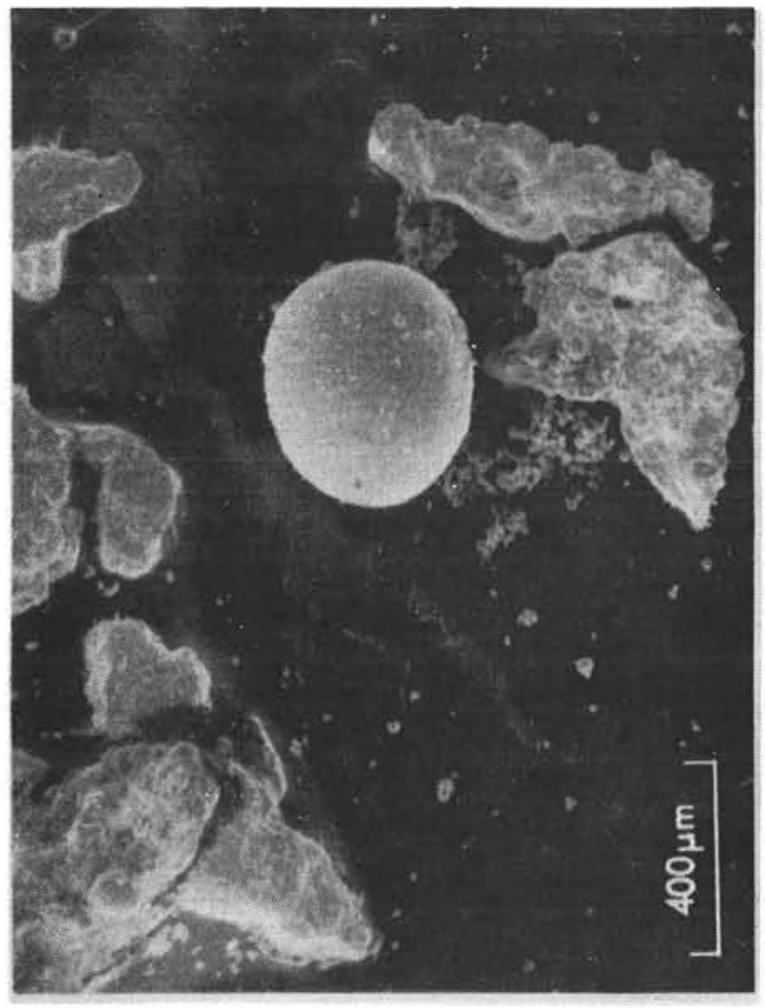

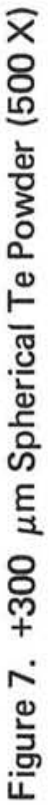




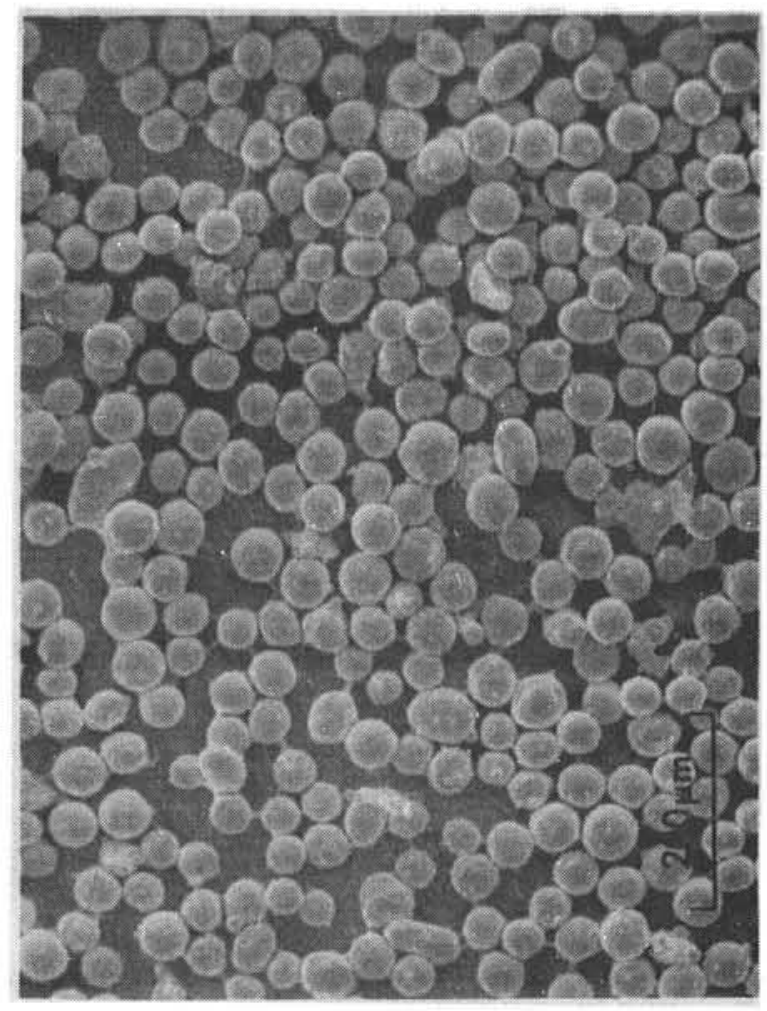

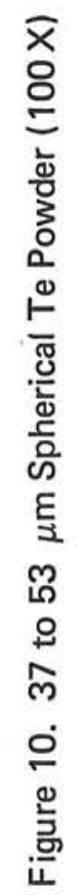

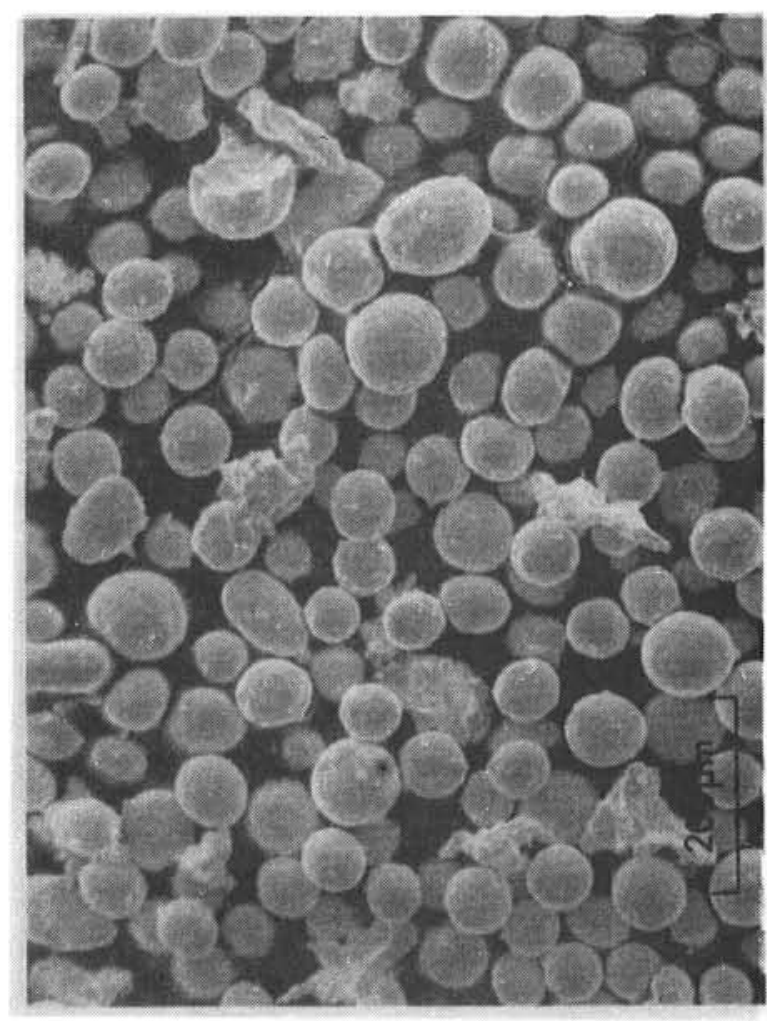

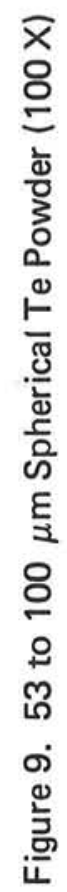




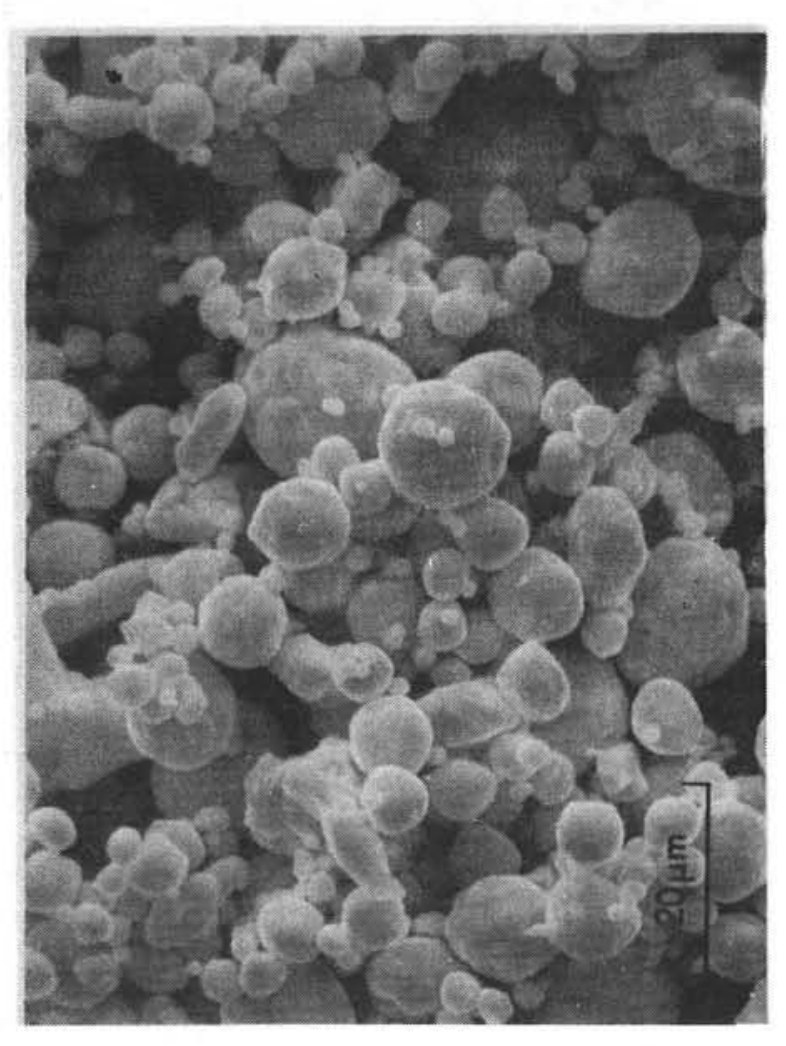

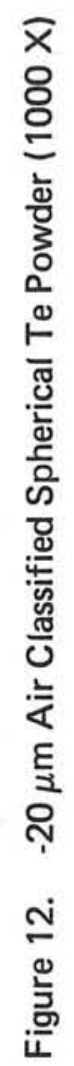

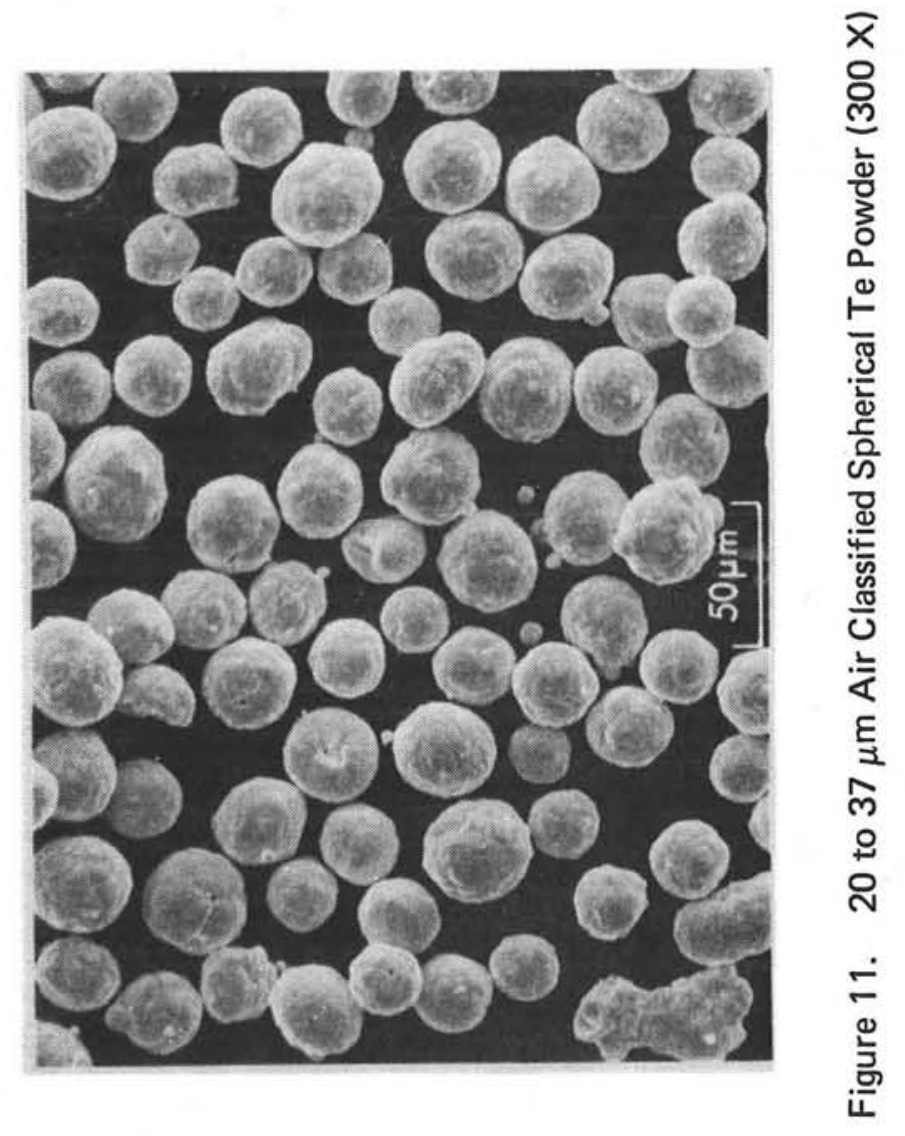


The particle size distributions are shown in Figure 13, and the mean sizes are listed in Table III. For comparison, the Zeiss distribution for the airelutriated irregular Te powder (see Figure 5) is also shown in Figure 13. Unfortunately, the Zeiss technique ignores any adherent fines, and thus the tabulated values are much larger than those listed as $\bar{d}_{N}$. Optical metallography revealed an internal porosity in the atomized powders, as illustrated in Figure 14. These voids represent shrinkage induced porosity associated with particle solidification. Polarized light microscopy quite successfully resolved the grain structure in these particles, as illustrated by Figure 15. The grain size was typically less than $10 \mu \mathrm{m}$ for all three powder fractions.

The three intermediate size classifications (20 to 37,37 to 53 , and 53 to $100 \mu \mathrm{m}$ ) represent near optimal Te powders. These powders provide a systematic increase in particle size, suitable for experimental determination of the thermite reaction property variations with particle size. Future efforts should be aimed at determining the particular particle size that provides the proper compromise between thermite reaction kinetics and long-term stability. If deemed necessary by future studies, these powders can be chemically vapor deposited with a stable metallic coating to enhance stability. An example of tungsten coated Te (thermally cracked $\mathrm{W}(\mathrm{CO})_{6}$ deposited on the 53 to $\left.100 \mu \mathrm{m} \mathrm{Te}\right)$ is shown in Figure 16a. One problem with this approach is the lack of coating adhesion, as illustrated in Figure $16 \mathrm{~b}$.

Summary

The characteristics of optimal Te powders for thermite-type reactions have been identified. The dominant concern is with the specific surface area. The technology involved in the production of "optimal" Te powders is described in detail. Fabrication of spherical Te powders has been achieved by argon atomization of liquid Te. The atomized material has been successfully classified into narrow size ranges by air classification with significant removal of adherent fines. The minimum powder characterization consists of examination by scanning electron microscopy coupled to nitrogen adsorption surface area determination. Future experiments should utilize the three "optimal" powder fractions described in this report to establish a particle size influence on the thermite reaction variables. 


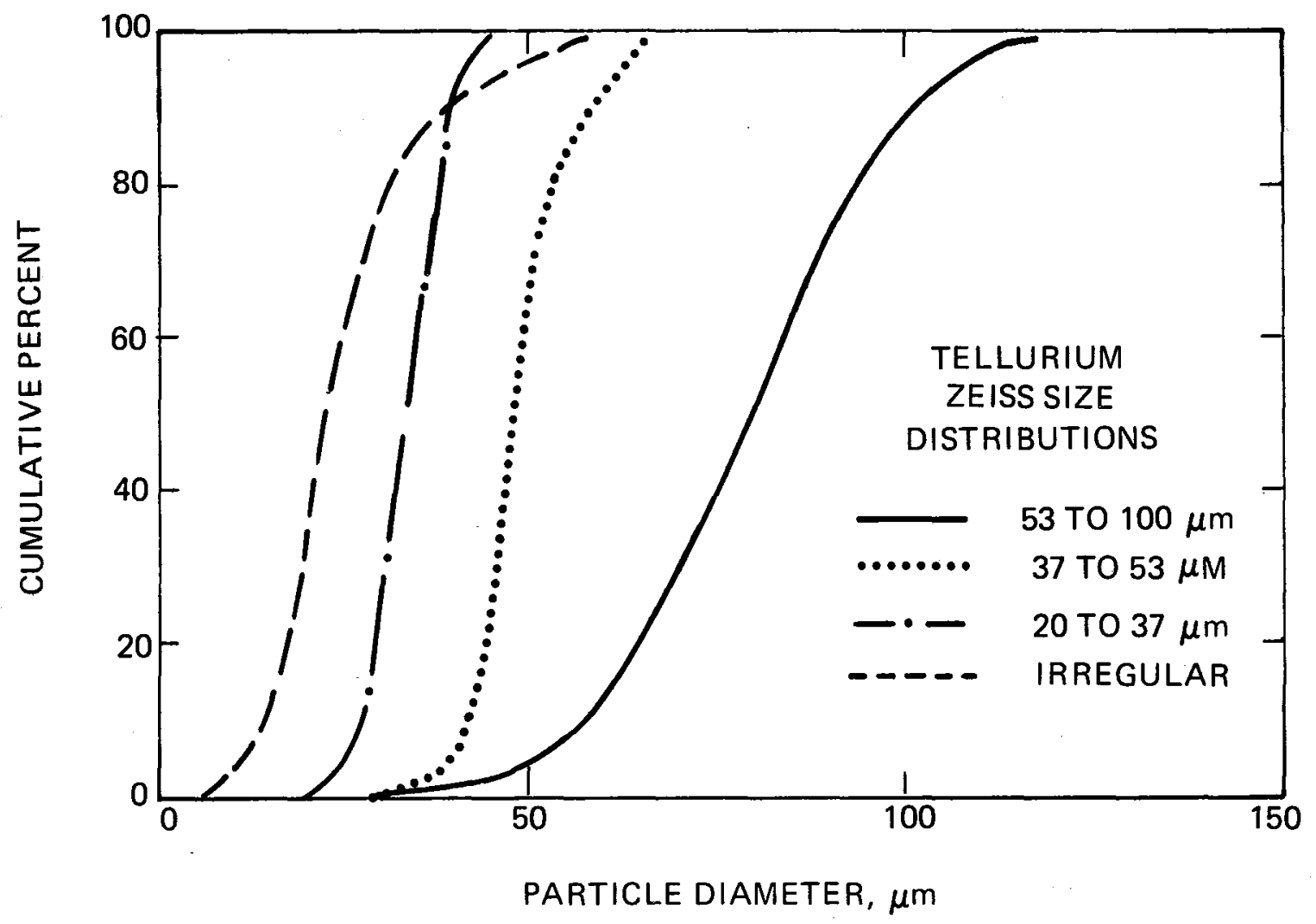

Figure 13. Ziess Particle Size Distributions for the Three Spherical Te Powders Shown in Figures 9, 10, and 11, and the Air-Elutriated Irregular Te Powder Shown in Figure 5. 
TABLE III

CLASSIFIED ATOMIZED TELLURIUM

Material Source - Kawecki Berylco

Atomized - Special Metals

Purity - 99. 99\% Te

Classified - Battelle Columbus

\begin{tabular}{rcccccc}
\hline Size Range & $\mathrm{S}, \mathrm{m}^{2} / \mathrm{g}$ & $\overline{\mathrm{d}}_{\mathrm{N}}, \mu \mathrm{m}$ & $\begin{array}{c}\text { Mean Size } \\
\text { Zeiss Analysis, } \mu \mathrm{m}\end{array}$ & $\begin{array}{c}\text { Figure } \\
\text { Number }\end{array}$ \\
\hline \hline$+300 \mu \mathrm{m}$ & 0.051 & 18.9 & Not measured & 7 & Agglomerates and coarse particles \\
100 to $300 \mu \mathrm{m}$ & 0.035 & 27.2 & Not measured & 8 & Many flakes \\
53 to $100 \mu \mathrm{m}$ & 0.048 & 19.9 & 80 & 9 & Uniform size, mostly all spheres \\
37 to $53 \mu \mathrm{m}$ & 0.062 & 15.4 & 48 & 10 & Uniform size, some agglomerates \\
20 to $37 \mu \mathrm{m}$ & 0.089 & 10.8 & 33 & 11 & Uniform \\
$-20 \mu \mathrm{m}$ & 0.237 & 4.1 & Not measured & 12 & Spherical, wide size range, some \\
\hline
\end{tabular}




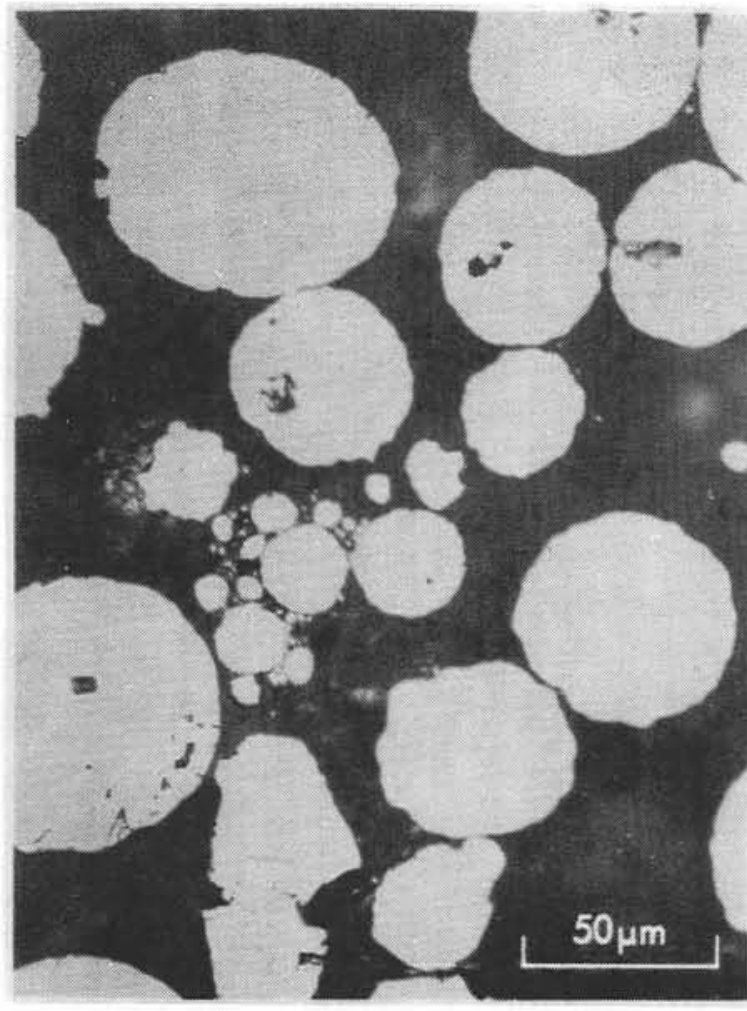

Figure 14. Optical Micrograph of Polished Cross Sections Through the 53 to $100 \mu \mathrm{m}$ Te Spheres (400 X)

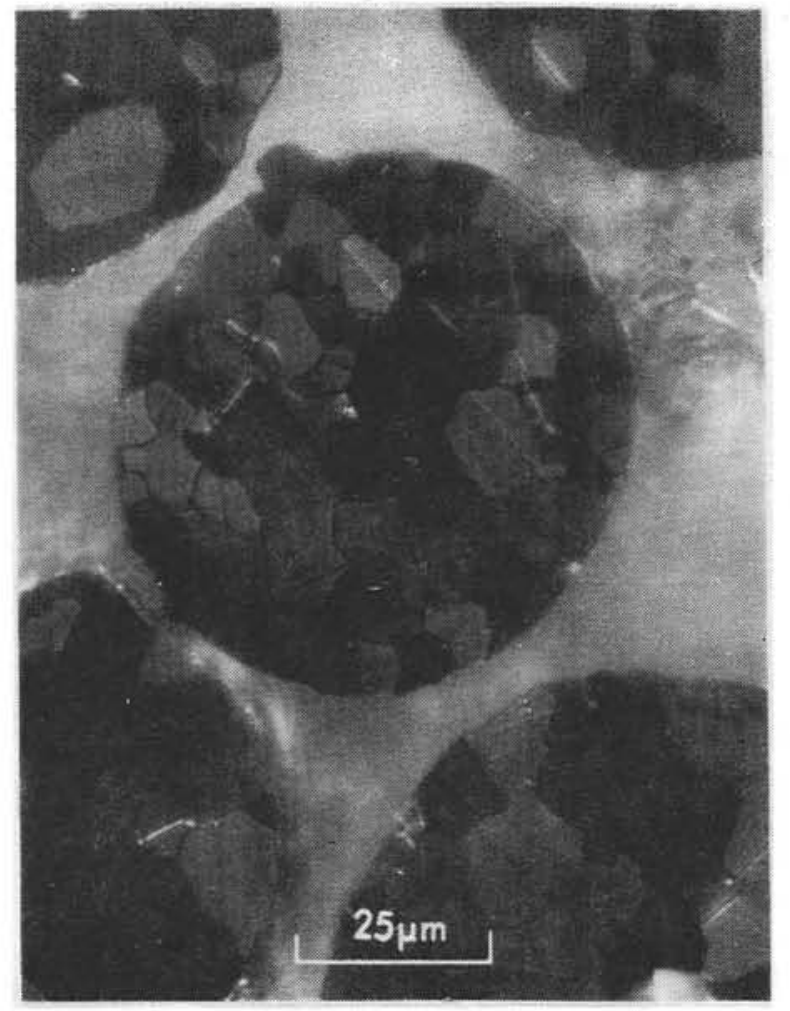

Figure 15. Polarized Light Micrograph Showing the Grain Structure in the 53 to $100 \mu \mathrm{m}$ Spherical Te Powder $(800 \mathrm{X})$ 


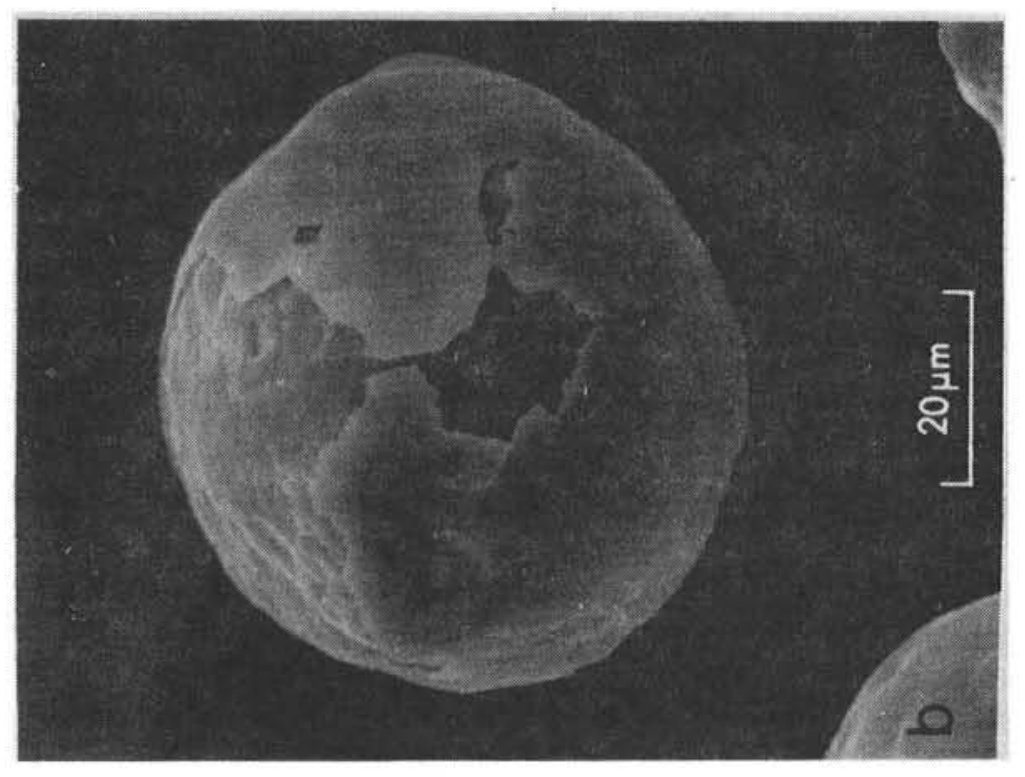

تٓ

$\stackrel{\circ}{\stackrel{0}{\circ}}$

등

के ह्र

토 듬

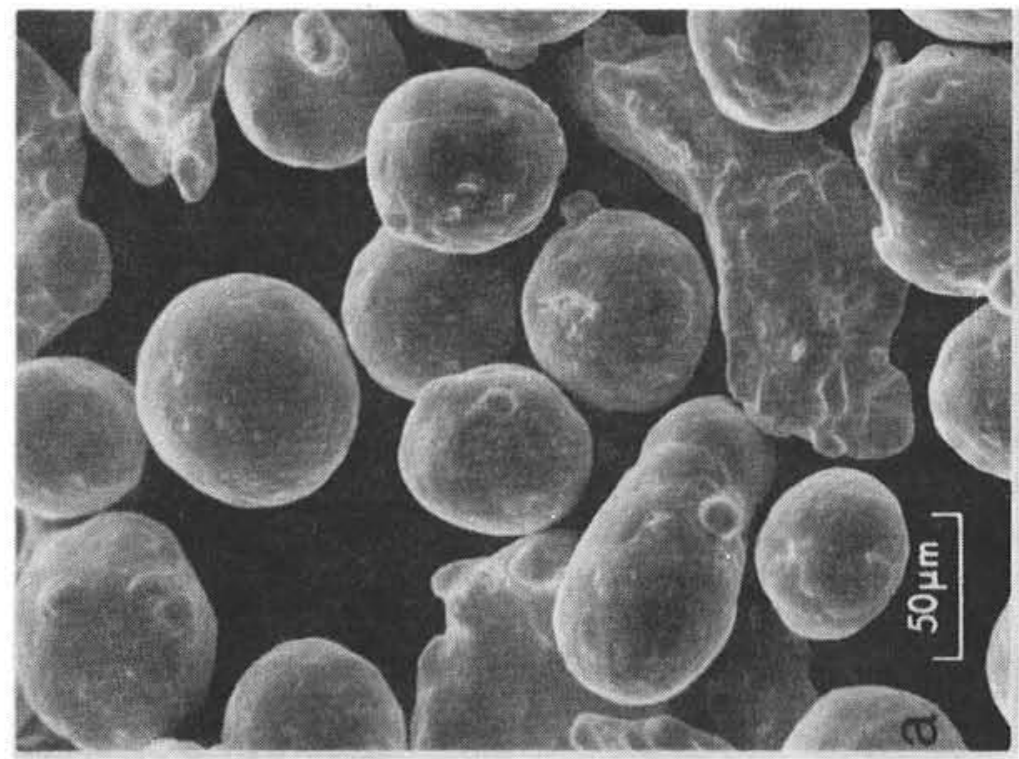

응 용

이

กี ญ

$\ddot{\theta}$

흔 
APPENDIX A

POWDER CHARACTERIZATION TECHNIQUES OUTLINE

\section{Specific Surface Area}

The specific surface area was measured using nitrogen absorption in accordance with the BET technique. ${ }^{8}$ The measurements were performed on a Quantachrome Quantasorb surface area analyzer. Prior to analysis, each sample was outgassed by heating at $200^{\circ} \mathrm{C}$ for 2 hours in flowing dry nitrogen. The surface area was determined by adsorbing nitrogen from a nitrogen plus helium gas mixture. Adsorption was measured by monitoring the gas mixture thermal conductivity. All adsorption measurements were performed at $77 \mathrm{~K}$, using $\mathrm{N}_{2} /$ He ratios of $2 / 18,4 / 16$, and $6 / 14$ (i. e. , three point $\mathrm{BET}$ ). The instrument settings and calculation constants for these determinations were optimized as: attenuation $=8$, bridge current $=180 \mathrm{ma}$, calibration volume $=0.06 \mathrm{~cm}^{3}$, saturation vapor pressure $=102 \mathrm{kPa}$, molecular weight of adsorbate $=28$, and adsorbate cross sectional area $=$ $16.2 \times 10^{-20} \mathrm{~m}^{2}$. The specific surface area was calculated from the threepoint adsorption measurements. 9

\section{Coulter Counter Particle Size Analysis}

The Coulter Counter provides a particle size distribution on either a weight or population basis. The size measurement is performed by passing an electrolyte contining the dispersed powder through a small aperture. Resistivity changes induced by particle motion through the aperture can be directly related to the particle size. ${ }^{9}$ The analyses at Sandia were performed on a Model TA-II instrument with a $100 \mu \mathrm{m}$ aperture tube (size range 2 to $40 \mu \mathrm{m})$. A $3 \% \mathrm{NaCl}$ electrolyte was used for all analyses. The powder samples were dispersed in electrolyte using 3 drops each of $1 \mathrm{wt}$. \% Calgon and 1 wt. \% Daxal 23 in $20 \mathrm{ml}$ fluid. The sample was ultrasonically agitated for a total of 80 minutes prior to analysis. The instrument was calibrated with $3.49 \mu \mathrm{m}$ latex spheres.

\section{Zeiss Particle Size Analysis}

The Zeiss particle size analysis uses a simple light system to optically sort photomicrograph images into appropriate size classes. 
Scanning electron micrographs with known magnifications were manually analyzed using the Zeiss instrument to establish particle size distributions. Colloidal graphite was used to ensure specimen conductivity and adhesion to the substrate in the microscope. 
APPENDIX B

TELLURIUM ATOMIZATION

Tellurium raw stock in the form of $1-\mathrm{cm}$ pieces was purchased from Kawecki Berylco Industries, Penn Rare Metals Division, Revere, PA. The material was $99.99 \%$ pure Te, containing only Se as a significant impurity $(\sim 50 \mathrm{ppm})$. The atomization was performed by a proprietary gas atomization process at Special Metals, Udimet Powder Division, Ann Arbor, MI.

Five-kg batches of the Te material were induction melted in a clay-graphite crucible. Charcoal was floated on top of the liquid Te to prevent oxidation. Atomization was performed at $600^{\circ} \mathrm{C}$ using pressurized argon and a zirconia/ alumina nozzle. The molten Te was atomized into a $0.38 \mathrm{~m}^{3}$ barrel that contained approximately $5 \times 10^{-2} \mathrm{~m}^{3}$ of water to aid in powder recovery. The molten Te seemed to wet the nozzle assembly, which caused difficulty in maintaining a uniform atomization. Three different atomization conditions were studied as identified in Table $A-I$, and lot 2 was used for the subsequent studies.

TABLE B-I

A TOMIZATION RESULTS

\begin{tabular}{cc}
\hline Lot & Specific Surface Area \\
\hline \hline 1 & 0.201 \\
2 & 0.112 \\
3 & 0.153 \\
\hline
\end{tabular}


REFERENCES

1. J. M. Dallavalle, Micromeritics, 2nd ed., Pitman Publishers, NY, 1948.

2. J. S. Hirschhorn, Powder Met. Inter., 1970, vol. 2, p. 83.

3. G. Herdan, Small Particle Statistics, 2nd ed., Academic Press, NY, 1960, p. 82 .

4. R. M. German, Correlation and Comparison of Particle Size Distributions, Sandia Laboratories, Livermore, SLL-73-0273, August 1973.

5. R. L. Brown and J. C. Richards, Principles of Powder Mechanics, Pergamon Press, NY, 1970.

6. R. M. German, Characterization of an ASTM Round-Robin Tungsten Powder, Sandia Laboratories, Livermore, SAND74-8631, November 1974.

7. R. M. German, Characterization of the 304L Stainless Steel Powder Used in Manufacturing Sintered Flow Devices, Sandia Laboratories, Livermore, SCL-DR-710323, December 1971.

8. S. Brunauer, P. H. Emmett, and E. Teller, J. Amer. Chem. Soc., 1938, vol. 60, p. 309.

9. T. Allen, Particle Size Measurement, 2nd ed., John Wiley \& Sons, NY, 1975. 
UNLIMITED RELEASE

\section{INITIAL DISTRIBUTION}

K. Phipps, MD; Attn: G. Downs, K. Foster, C. Love

W. G. Northcutt, $Y-12$

M. F. Browning, BCL

E. Kjeldgaard, 2515; Attn: A. Heckes

M. J. Davis, 5830

H. J. Saxton, 5840; Attn: E. K. Beauchamp

M. Moss, 5842

C. Northrup

T. B. Cook, Jr., 8000; Attn: C. H. DeSelm, 8200

W. C. Scrivner, 8400

L. Gutierrez, 8100; Attn: R. M. Green, 8111

B. F. Murphey, 8300

D. M. Schuster, 8310

D. R. Adolphson, 8312

R. IM. German, 8312 (10)

V. Ham, 8312 (10)

R. W. Mar, 8313

M. C. Nichols, 8313

G. W. Anderson, 8330; Attn: J. E. Marion, 8332

K. Battleson, 8332

L. Tallerico, 8332

K. Tschritter, 8332

W. Bauer, 8334; Attn: P. Coronado, M. Malinowski, R. Musket, W. Swansiger, G. Thomas, K. Wilson

Technical Publications and Art Division, 8265, for TIC (2)

F. J. Cupps, 8265/Technical Library Processes Division, 3141

Technical Library Processes Division, 3141 (2)

Library and Security Classification Division, 8266-2 (3) 